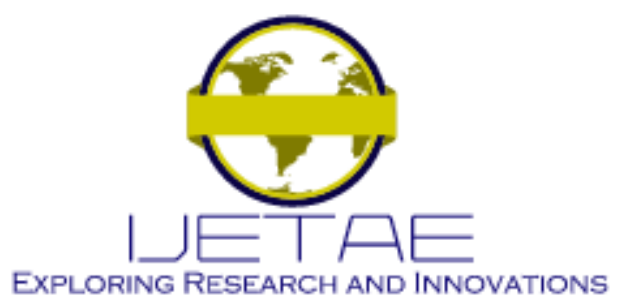

International Journal of Emerging Technology and Advanced Engineering

Website: www.ijetae.com (E-ISSN 2250-2459, Scopus Indexed, ISO 9001:2008 Certified Journal, Volume 12, Issue 02, February 2022)

\title{
New Approach to Identify the Most Sustainable Supplier Based on IFS
}

\author{
Oussama El Mariouli ${ }^{1}$, Abdellah Abouabdellah ${ }^{2}$ \\ ${ }^{1,2}$ National School of Applied Science, University Ibn Tofail, Kenitra, Morocco
}

\begin{abstract}
To meet the expectations of consumers, who are increasingly demanding products that respect the concept of sustainable development (SD), companies are called upon to engage in an SD approach that begins with the selection of suppliers, taking into consideration the environmental, social and economic criteria. In this paper, we present a new model of selecting the best sustainable supplier. We have developed a hybrid model, which is built by extending the fuzzy set (FS) to the intuitionistic fuzzy set theory (IFS) and with the Decision Making Trial and Evaluation Laboratory (DEMATEL) method. Our model presented, allows us to measure the weight of the selected criteria of SD, to present an approach for defining the SD strategy within companies and finally to choose among the suppliers, the best supplier who respects the concept of SD by taking into consideration the links between the axe of SD. The results of the application of our approach have shown that our model can be easily used in all companies wishing to select sustainable suppliers.
\end{abstract}

Keywords-Sustainable supplier selection; sustainable development; criteria; DEMATEL; intuitionistic fuzzy set; supply chain management.

\section{INTRODUCTION}

The emergence towards the new concept of SD nowadays, customers have become more demanding of products that respect SD. This change in national and international markets has forced industrial companies to integrate the concept of SD into the management of their supply chains. This change is mandatory for companies to remain competitive, to open up to new national and international markets and to face the various pressures (NGOs, the media, the State, civil society and other economic actors who demand economic development that is more respectful of the environment and society).

The integration of the SD concept into the logistics chain begins with the selection of sustainable suppliers, in view of the positioning of the supplier selection process upstream of the logistics chain.
The purchase of environmentally friendly raw materials for industrial companies is important for the continuity of existence, improvement and competitiveness of the company. We can cite the example of Sony who used hazardous materials in the manufacture of PlayStation consoles and Mattel who used a material contaminated with lead to paint toys [1], these companies risked losing their image as brand in the market. Therefore, to avoid this kind of problem, it is necessary to choose the partners upstream "suppliers" by determining the right SD criteria in the selection process.

During the last five years, in the literature we find several studies [2, 3, 4] which have started to discuss the problem of selection of sustainable suppliers (SSS), but all these studies do not really study the interrelation between the SD criteria in the supplier selection process.

In this paper, we will present a model, which allows us to calculate the performance index of suppliers, by taking into consideration the interrelation between the different SD criteria in the calculation (see next section). Our model is based on the combination of:

- The extension of FS: The theory of fuzzy sets FS developed by [5], is used to answer the problems of uncertainties and imprecision of choice. FS is based on the principle that all these elements belong to the bounded interval of zero to one, but it is not true in al time that the degree of non-membership of an element of FS equals 1 minus the degree of membership, there is always a degree of hesitation. To solve this hesitation problem, Atanassov proposed a generalization of FS, an IFS [6,7]. IFS is used to address the weakness the FS [8,9].

- The DEMATEL method presented by Gabus and Fontela in Battelle Memorial Institute [10], it is used to build the interrelationships between the criteria and also to analyze and visualize the interactions between these criteria on the diagram cause and effect. 


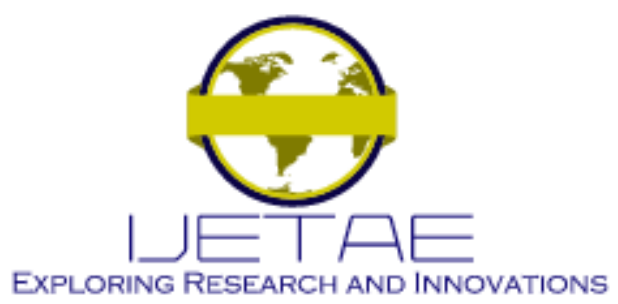

International Journal of Emerging Technology and Advanced Engineering

Website: www.ijetae.com (E-ISSN 2250-2459, Scopus Indexed, ISO 9001:2008 Certified Journal, Volume 12, Issue 02, February 2022)

In the literature, we find that IF DEMATEL has been used recently by several authors [2, 11, 12, 13, 14], which shows their efficiency and flexibility elaborate uncertainty and vagueness opinion involved in decision making (DM) by manager for calculate of the weights of the criteria.

The originality of our developed model allows us to measure and classify suppliers according to their sustainability performance indices, taking into account the interdependence between the three dimensions of SD (see the next section).

Our article is made up as follows: The first part introduces the concept of sustainable suppliers. The second part presents our developed model, which allows us to measure the sustainability performance index of suppliers. The third part shows the application of the developed model. The fourth part discusses the results obtained and the results. The last part contains the conclusion. In the following section we present the originality of our work

\section{LITERATURE REVIEW}

In the literature, quite a few studies deal with the subject of selecting sustainable suppliers. We find the study by Amiri and al in 2020, who proposed a fuzzy model based on the Best-Worst Method (BWM) [15]. Lit and al in 2019, who develop an approach that uses the method Technique for Order Performance by Similarity to Ideal Solution [16]. Giannakis and al in 2019, who used the Analytical Network Process (ANP) for the evaluation and selection of suppliers [17]. Abdel-Baset and al in 2019, who used a combination of two method ANP and ViseKriterijumska Optimizacija I Kompromisno Resenje (VIKOR) for supplier selection [18]. Chen and al in 2019, propose a framework to select suppliers by using rough-fuzzy approach [19].

Analysing recent work on the issue of selecting sustainable suppliers, we find that all the researchers in the review literature have studied this issue without taking into consideration the intersection between the three dimensions of sustainable development. All the approaches developed in the review literature, list the supplier selection criteria by the dimension and integrate them into a model that allows the selection of suppliers, without studying the relationship between the dimensions.

\section{SUSTAINABLE SUPPLIER}

The SD concept appeared in 1987, in the report entitled "Our Common Future" [20].
We considered a sustainable supplier, if he respects the conditions of the three following interdependencies between dimensions of SD:

- Suppliers will have to link the two dimensions: environmental and economic. This is what you call being viable. Viable is the state where the environment provides natural resources that are exploitable and essential to the survival of the economy ... and in the long term. In another way, for the economy to be sustainable and beneficial for future generations, natural resources will need to be properly harnessed and managed.

- Suppliers will have to achieve the intersection between the two dimensions: environmental and social. This is what you call being livable. Livable is the healthy environment that provides food, clean water, quality air, shelter and jobs for a society ... an environment in which we can live.

- Suppliers will have to join the economic dimension to the social dimension. This is called being equitable. Equitable is the case where all members of a society can have fair incomes, long-term jobs, and quality goods and services, thanks to an economy that is well managed and sustainable.

Graphically, these three conditions refer to the intersections between the social, environmental and economic dimensions, commonly called the "interfaces". In addition, the "sustainable" is at the confluence of these three interfaces as shown in Figure 1.

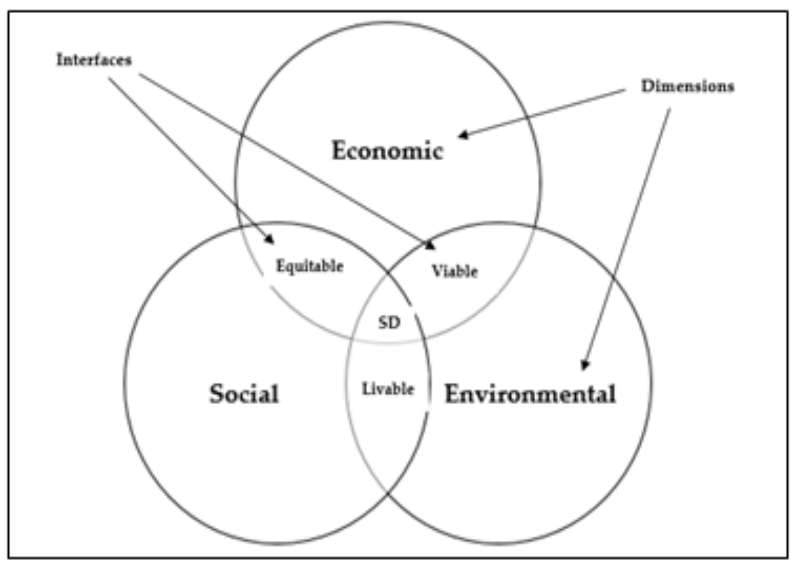

FIGURE I THE INTERSECTIONS BETWEEN SD DIMENSION 


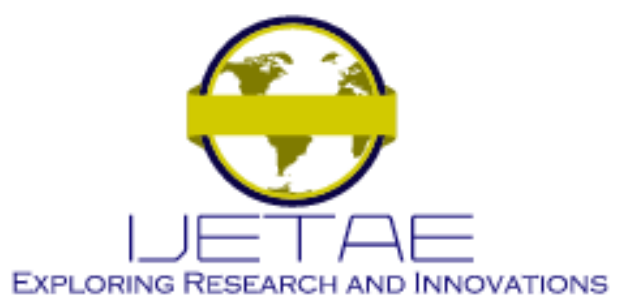

International Journal of Emerging Technology and Advanced Engineering

Website: www.ijetae.com (E-ISSN 2250-2459, Scopus Indexed, ISO 9001:2008 Certified Journal, Volume 12, Issue 02, February 2022)

\section{THE THEORETICAl CONCEPT AND PROPOSED} METHODOLOGY

\section{A. Preliminary of IFS}

Let $X$ a nonempty set.

An IFS A in $X$ is presented as follows:

$$
A=\left\{\left(x, \mu_{A}(x), v_{A}(x)\right\}: x \in X\right\}
$$

Where $\mu_{A}(x), v_{A}(x): X \rightarrow[0,1]$, And

$$
0 \leq \mu_{A}(x)+v_{A}(x) \leq 1 \quad \forall x \in X
$$

$\mu_{A}(x)$ and $v_{A}(x)$ represent the degree of membership and non-membership respectively of $x \in X$ to the set $A$.

Another concept related to IFS represent the hesitancy degree:

$$
\pi_{A}(x)=1-\mu_{A}(x)-v_{A}(x)
$$

$\pi_{A}(x)$ represent the degree of uncertainty of $x \in X$ to the $\operatorname{IFS} A$.

\section{B. Proposed methodology}

In this part, we will present our approach to selecting the best sustainable suppliers who respect the three pillars of sustainable development.

Step 1: Identification the economic, environmental and social criteria for sustainable development:

These criteria are derived from the analysis of literature reviews since the first articles (Dickson, 1966) which published a list of supplier selection criteria. Also the result of the analysis of national and international standards such as the Supply-Chain Operations Reference (SCOR), the GRI (Global Reporting Initiative), the Organisation for Economic Co-operation and Development (OECD) and the International Organization for Standardization (ISO) 26000 ... In our paper [21], we presented the most criteria used in literature reviews from 1966 to 2016.

Step 2: Determination of the linguistic terms for the IFDEMATEL approach:

Table I shows these linguistic terms in IFS.
TABLE I

LINGUISTIC TERMS FOR IF-DEMATEL

\begin{tabular}{|l|l|}
\hline Definition of Linguistic Terms & IFS \\
\hline NI : No Influence & $(0.00,1.00,0.00)$ \\
\hline LI : Low Influence & $(0.35,0.60,0.05)$ \\
\hline MI : Medium Influence & $(0.50,0.45,0.05)$ \\
\hline HI : High Influence & $(0.75,0.20,0.05)$ \\
\hline VHI : Very High Influence & $(0.90,0.10,0.00)$ \\
\hline
\end{tabular}

Step 3: Calculate the weight of DM:

To define the importance of DM relative to their experience and knowledge, we use the linguistic scale as shown in Table II. We take $D_{k}=\left[\mu_{k}, v_{k}, \pi_{k}\right]$ as an IF number for weighting the kth DM. The priority value of the $\mathrm{DM}$ is obtained as follows:

$$
\lambda_{k}=\frac{\mu_{k}+\pi_{k}\left(\frac{\mu_{k}}{\mu_{k}+v_{k}}\right)}{\sum_{k=1}^{1}\left(\mu_{k}+\pi_{k}\left(\frac{\mu_{k}}{\mu_{k}+v_{k}}\right)\right)}
$$

TABLE II

Linguistic terms for calculate the weight of DM

\begin{tabular}{|l|l|}
\hline Definition of Linguistic Terms & IFS \\
\hline VU : Very Unimportant & $(0.10,1.80,0.10)$ \\
\hline U : Unimportant & $(0.25,0.60,0.15)$ \\
\hline MI : Medium Important & $(0.50,0.40,0.10)$ \\
\hline I : Important & $(0.75,0.20,0.05)$ \\
\hline VI : Very Important & $(0.90,0.05,0.05)$ \\
\hline
\end{tabular}

Step 4: Calculation of the weights of the different SD criteria:

In this step, we calculate the weight of the different criteria of each axe of SD. We use the extension of the Fuzzy DEMATEL to Intuitionistic Fuzzy DEMATEL as follow to calculate the weight:

- Calculate the Aggregated IF Decision Matrix according to the DM opinions

Let $A^{k}=\left(a_{i j}^{k}\right)_{m \times n}$ is an IF decision matrix for each DM, and $\lambda=\left\{\lambda_{1}, \lambda_{2, \ldots,} \lambda_{1}\right\}$ DM weights, where $\sum_{k=1}^{1} \lambda_{k}=1, \lambda_{k} \in[0,1]$. The group selection procedure is based on the grouping of all the single opinions of the MD; we use IFWA (IF Weighted Averaging) function [23] to group the indices of importance of all criteria. 


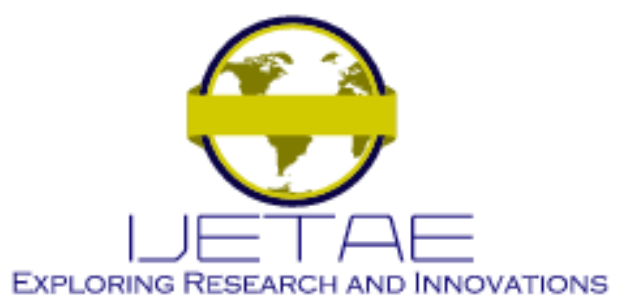

International Journal of Emerging Technology and Advanced Engineering

Website: www.ijetae.com (E-ISSN 2250-2459, Scopus Indexed, ISO 9001:2008 Certified Journal, Volume 12, Issue 02, February 2022)

With $A_{i j}^{(k)}=\left\{\mu_{i j}^{(k)}, v_{i j}^{(k)}, \pi_{i j}^{(k)}\right\}$ as IFS that used by the kth DM with ${ }^{a_{i j}}$.

$a_{i j}:$ Represent the criteria.

Using IFWA, we can calculate the aggregated intuitionistic fuzzy relation as following:

$$
\begin{aligned}
& a_{\mathrm{ij}}=I F W A_{\lambda}\left(a_{\mathrm{i} j}^{(\mathbb{1})}, a_{\mathrm{i} j}^{(2)}, \ldots, a_{\mathrm{i} j}^{(\mathbb{D})}\right) \\
& =\lambda_{1} a_{i j}^{[(1)} \oplus \lambda_{2} a_{i j}^{[2]} \oplus, \ldots, \lambda_{i} a_{i j}^{\mathbb{Q D}} \\
& =\left[1-\prod_{k=1}^{1}\left(1-\mu_{i j}^{(k)}\right)^{\lambda_{k}}, \prod_{k=1}^{1}\left(v_{i j}^{(k)}\right)^{\lambda_{k}}, \prod_{k=1}^{1}\left(1-\mu_{i j}^{(k)}\right)^{\lambda_{k}}-\prod_{k-1}^{\mathbb{1}}\left(v_{i j}^{(k)}\right)^{\lambda_{k}}\right]
\end{aligned}
$$

Where:

$$
\begin{aligned}
a_{i j}^{[k j)} & =\left(\mu_{A i}\left(x_{j}\right), v_{A i}\left(x_{j}\right), \pi_{A i}\left(x_{j}\right)\right) \\
(i & \left.=1,2, \ldots, m_{i} j=1,2, \ldots, n\right)
\end{aligned}
$$

- Construct the Direct Relation IF Matrix A:

In this step, DM are called to answer a questionnaire to give the values of non-membership, membership and hesitancy proposed between the criteria. We use theses variables, we obtain a non-negative matrix $(\mathrm{n} \times \mathrm{n})$, which represents the Direct Relation IF Matrix $A_{z}^{(k)}$.

$z=\left(\mu_{i j}, v_{i j}, \pi_{i j}\right):$ Represent the impact relation of the criterion $i$ to the criterion $j$.

$$
A_{z}^{(k)}=\left[\begin{array}{cccc}
0 & A_{z_{12}}^{(k)} & \ldots & A_{z_{1 n}}^{(k)} \\
A_{z_{21}}^{(k)} & 0 & \ldots & A_{z_{2 n}}^{(k)} \\
\vdots & \vdots & 0 & \vdots \\
A_{z_{n 1}}^{(k)} & A_{z_{n 2}}^{(k)} & \ldots & 0
\end{array}\right]
$$

\section{- Defuzzify the Direct Relation IF Matrix X:}

We calculate the defuzzify value of the aggregated intuitionistic fuzzy relation by using the equation bellow:

$$
\bar{r}_{i j}=\mu_{i j}-v_{i j}+(2 \beta-1) \pi_{i j}
$$

$\beta$ represent the risk neutral, where $(\beta=0,5)$.

We obtain defuzzify the Direct Relation Intuitionistic Fuzzy Matrix X as follow:

$$
X=\left[\begin{array}{ccc}
0 & \cdots & \bar{r}_{1 n} \\
\vdots & \cdots & \vdots \\
\bar{x}_{n 1} & \cdots & 0
\end{array}\right]
$$

- Construct the Normalized Direct Relational IF Matrix $N$ :

$\mathbb{N}_{z}^{k}$ is given by:

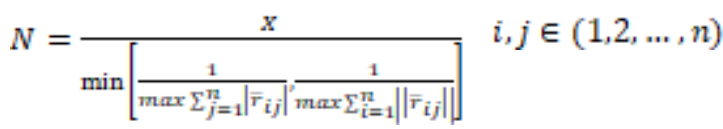

- Construct the Total Relation IF Matrix T:

We obtain $\mathrm{T}$ like as:

$$
T=N(1-N)^{-1}
$$

\section{- Calculate the Cause/Effect groups:}

We construct the impact digraph map by using the horizontal $\left(r_{\mathrm{i}}+c_{\mathrm{i}}\right)$ and vertical $\left(r_{\mathrm{i}}-c_{\mathrm{i}}\right)$ axes.

$r_{\mathbb{1}}:$ Sum of the jth row

$c_{\mathrm{i}}$ : Sum of the ith column

$$
\begin{aligned}
& \tilde{T}_{z}=\left[\tilde{t}_{z_{i j}}\right]_{n \times n} \\
& r_{i \mathfrak{i}}=\left[\sum_{j=1}^{n} \tilde{t}_{i j}\right]_{n \times 1} \\
& c_{i j}=\left[\sum_{i=1}^{n} \tilde{t}_{i j}\right]_{1 \times n}
\end{aligned}
$$

If the vertical axis are positive, the indicate a causal factor, else the indicate the effect in the group.

- Obtain the weights of criteria:

We obtain the weights of different criteria of SD by the following equation:

$$
W_{i}=\frac{\sqrt{\left(r_{i}+c_{i}\right)^{2}+\left(r_{i}-c_{i}\right)^{2}}}{\sum_{i}^{n} \sqrt{\left(r_{i}+c_{i}\right)^{2}+\left(r_{i}-c_{i}\right)^{2}}}
$$

Step 5: Calculates values of selected criteria

In this step we calculate the values of each criterion selected in step 1 by using the equation developed in our article [22]. 


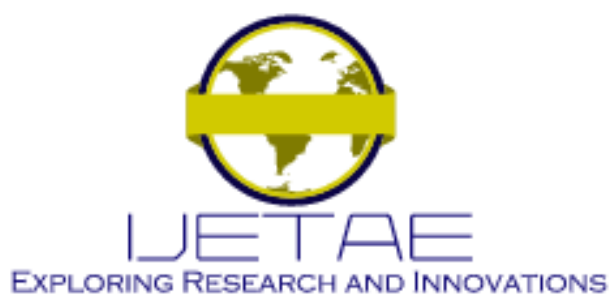

International Journal of Emerging Technology and Advanced Engineering Website: www.ijetae.com (E-ISSN 2250-2459, Scopus Indexed, ISO 9001:2008 Certified Journal, Volume 12, Issue 02, February 2022)

The values of the criteria are bounded between zero and one.

For example, we take the reactivity criteria of the economic dimension:

Reactivity: It is the capability to respond quickly and easily to fluctuating needs in the market.

The equation for calculating the criteria value (C) of reactivity is show as follow:

$$
C=\frac{1}{C_{\mathrm{Re} \text { activity }}}, \quad C_{\mathrm{Re} \text { activity }}=\left\{\begin{array}{c}
\text { 1ifGood } \\
\text { 2ifAverage } \\
\text { 3ifLow }
\end{array}\right.
$$

Step 6: Choice of scenario for SD strategy:

In this step we choose a scenario for define the weight of SD dimensions according to the strategy followed by the company, as shown in the Table III. We calculate the weight in such a way that:

$$
\begin{gathered}
W_{\text {economic }}+W_{\text {environmental }}+W_{\text {social }}=1 \\
W_{\text {economic }}>0, W_{\text {environmental }}>0, W_{\text {social }}>0 \\
W_{\text {economic }} W_{\text {environmental and }} W_{\text {social }} \text { : Weight of } \\
\text { economic, environmental and social dimension }
\end{gathered}
$$
successively.

TABLE III

DIFFERENT SCENARIO TO DEFINE THE WEIGHT OF SD DIMENSIONS

\begin{tabular}{|l|}
\hline Different scenario possible \\
\hline$W_{\text {economic }}=W_{\text {environmental }}=W_{\text {social }}$ \\
\hline$W_{\text {economic }}>W_{\text {environmental }}>W_{\text {social }}$ \\
$W_{\text {economic }}>W_{\text {social }}>W_{\text {environmental }}$ \\
\hline$W_{\text {environmental }}>W_{\text {economie }}>W_{\text {social }}$ \\
\hline$W_{\text {environmental }}>W_{\text {social }}>W_{\text {economic }}$ \\
$W_{\text {social }}>W_{\text {economic }}>W_{\text {environmental }}$ \\
\hline$W_{\text {social }}>W_{\text {environmental }}>W_{\text {economie }}$ \\
\hline
\end{tabular}

Step 7: Calculate the social, environmental and economic index:

In this step we calculate the economic, environmental and social index of each supplier, such as:

$$
I_{\text {economique }}=\sum_{i=1}^{n} W_{i} C_{i}
$$

$$
I_{\text {environmental }}=\sum_{\mathrm{i}=1}^{m} W_{\mathrm{i}} C_{\mathrm{i}}
$$

$$
I_{\text {social }}=\sum_{i=1}^{k} W_{i} C_{i}
$$

$I_{\text {economique }} I_{\text {environmental }}$ and $I_{\text {social }}$ represent the economic, environment and social index successively.

$\mathrm{n}, \mathrm{m}$ and $\mathrm{k}$ : Number of economic, environment and social criteria successively.

$W_{i}$ : Weight of criteria i.

$C_{i}$ : Numeric value of the criteria $i$, where $C_{i} \in[0,1]$.

Step 8: Calculate the index of tree interfaces de SD:

In this step we calculate the tree index of interfaces of $\mathrm{SD}$ as follow:

- Index of viable interface: precaution/prevention, empowerment, robustness of choices, adaptability, etc.

$$
I_{\text {viable }}=I_{\text {economique }} \times I_{\text {environmental }} \times 10
$$

- Index of the livable interface: the living environment, the effects on health and safety, acceptance of the population, lifestyle, etc.

$$
I_{\text {wivable }}=I_{\text {environmental }} \times I_{\text {social }} \times 10
$$

- Index of the equitable interface: accessibility to the greatest number, intergenerational and intergenerational equity, sharing of wealth, compensation for prejudices, etc.

$$
I_{\text {equitable }}=I_{\text {economique }} \times I_{\text {social }} \times 10
$$




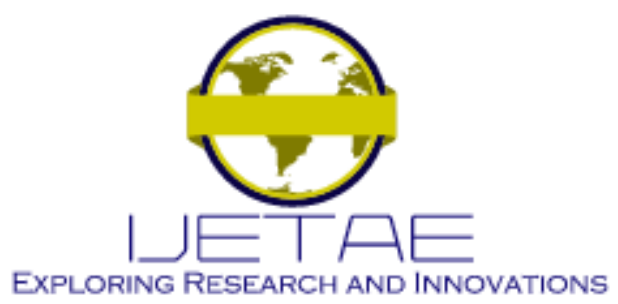

International Journal of Emerging Technology and Advanced Engineering

Website: www.ijetae.com (E-ISSN 2250-2459, Scopus Indexed, ISO 9001:2008 Certified Journal, Volume 12, Issue 02, February 2022)

Step 9: Calculate the supplier sustainability performance index:

In this step we calculate supplier sustainability performance index:

$$
I_{\text {Sustinaibility }}=I_{\text {viable }} \times I_{\text {vivable }} \times I_{\text {equitable }}
$$

\section{APPLICATION}

In this step, we will apply our developed method to choose between five suppliers. We calculate the performance index of each supplier. Then we choose the one between them, which most respects the concept of SD. A. The calculation of the sustainability performance index
of the supplierl

Step 1: Identification the criteria:

For illustration example of the developed method we use some criteria from our work [22], as shown in Table IV.

TABLE IV

THE CRITERIA OF SD

\begin{tabular}{|c|c|c|}
\hline \multicolumn{3}{|l|}{ Criteria } \\
\hline Economic & Environmental & Social \\
\hline $\operatorname{Cost}\left(\mathrm{C}_{1}\right)$ & Recycling $\left(\mathrm{C}_{6}\right)$ & Human rights $\left(C_{11}\right)$ \\
\hline Delivery $\left(\mathrm{C}_{2}\right)$ & $\begin{array}{l}\text { Use of } \\
\text { Resources }\left(\mathrm{C}_{7}\right)\end{array}$ & $\begin{array}{l}\text { Health and security } \\
\text { at work }\left(\mathrm{C}_{12}\right)\end{array}$ \\
\hline Quality $\left(\mathrm{C}_{3}\right)$ & $\begin{array}{l}\text { Environmental } \\
\text { label }\left(\mathrm{C}_{8}\right)\end{array}$ & $\begin{array}{l}\text { Training, support } \\
\text { and education }\left(\mathrm{C}_{13}\right)\end{array}$ \\
\hline Flexibility $\left(\mathrm{C}_{4}\right)$ & Pollution $\left(\mathrm{C}_{9}\right)$ & $\begin{array}{l}\text { Condition of work } \\
\left(\mathrm{C}_{14}\right)\end{array}$ \\
\hline $\begin{array}{l}\text { Technical and } \\
\text { technological } \\
\text { Capacity }\left(\mathrm{C}_{5}\right)\end{array}$ & Program $\left(\mathrm{C}_{10}\right)$ & $\begin{array}{l}\text { Jobs and wealth } \\
\left(\mathrm{C}_{15}\right)\end{array}$ \\
\hline
\end{tabular}

Step 2: We use Table 1 for to fix IF-DEMATEL:

Step 3: Calculate the weight of DM:

For this study, we have three managers of different years of experience to evaluate the selected criteria. We apply Equation (4) we obtain the importance weight of each manager, as shown in Table $\mathrm{V}$.
TABLE V

DM WEIGHT

\begin{tabular}{|l|l|l|l|}
\hline DM & $\begin{array}{l}\text { Number of } \\
\text { experience }\end{array}$ & $\begin{array}{l}\text { Importan } \\
\text { ce values }\end{array}$ & DM weight \\
\hline Manager1 & 2O year & VI & 0,413265306 \\
\hline Manager2 & 15 year & I & 0,344387755 \\
\hline Manager3 & 10 year & MI & 0,242346939 \\
\hline
\end{tabular}

Step 4: Calculation of criteria weights:

In this step, DM are asked to compare between the criteria selected in each dimension to indicate the relationships of influence.

For example, the intuitionistic judgments for economic dimension given by manager1 is shown in Table VI.

TABLE VI

MANAGER1 INTUITIONISTIC JUDGMENTS FOR ECONOMIC DIMENSION

\begin{tabular}{|l|l|l|l|l|l|}
\hline Manager $^{1}$ & $\mathbf{C}_{\mathbf{1}}$ & $\mathbf{C}_{\mathbf{2}}$ & $\mathbf{C}_{\mathbf{3}}$ & $\mathbf{C}_{\mathbf{4}}$ & $\mathbf{C}_{\mathbf{5}}$ \\
\hline $\mathrm{C}_{1}$ & $\mathrm{NI}$ & $\mathrm{HI}$ & $\mathrm{HI}$ & $\mathrm{HI}$ & $\mathrm{MI}$ \\
\hline $\mathrm{C}_{2}$ & $\mathrm{VHI}$ & $\mathrm{NI}$ & $\mathrm{HI}$ & $\mathrm{HI}$ & $\mathrm{LI}$ \\
\hline $\mathrm{C}_{3}$ & $\mathrm{VHI}$ & $\mathrm{HI}$ & $\mathrm{NI}$ & $\mathrm{LI}$ & $\mathrm{VHI}$ \\
\hline $\mathrm{C}_{4}$ & $\mathrm{HI}$ & $\mathrm{HI}$ & $\mathrm{HI}$ & $\mathrm{NI}$ & $\mathrm{LI}$ \\
\hline $\mathrm{C}_{5}$ & $\mathrm{HI}$ & $\mathrm{HI}$ & $\mathrm{HI}$ & $\mathrm{HI}$ & $\mathrm{NI}$ \\
\hline
\end{tabular}

For example, the intuitionistic judgments for environmental dimension given by manager1 is shown in Table VII.

TABLE VII

MANAGER $^{1}$ INTUITIONISTIC JUDGMENTS FOR ENVIRONMENTAL DIMENSION

\begin{tabular}{|l|l|l|l|l|l|}
\hline Manager $^{1}$ & $\mathbf{C}_{\mathbf{6}}$ & $\mathbf{C}_{\mathbf{7}}$ & $\mathbf{C}_{\mathbf{8}}$ & $\mathbf{C}_{\mathbf{9}}$ & $\mathbf{C}_{\mathbf{1 0}}$ \\
\hline $\mathrm{C}_{6}$ & $\mathrm{NI}$ & $\mathrm{VHI}$ & $\mathrm{HI}$ & $\mathrm{HI}$ & VHI \\
\hline $\mathrm{C}_{7}$ & $\mathrm{HI}$ & $\mathrm{NI}$ & $\mathrm{VHI}$ & $\mathrm{HI}$ & $\mathrm{LI}$ \\
\hline $\mathrm{C}_{8}$ & $\mathrm{VHI}$ & $\mathrm{HI}$ & $\mathrm{NI}$ & $\mathrm{HI}$ & $\mathrm{HI}$ \\
\hline $\mathrm{C}_{9}$ & $\mathrm{HI}$ & $\mathrm{HI}$ & $\mathrm{HI}$ & $\mathrm{NI}$ & $\mathrm{HI}$ \\
\hline $\mathrm{C}_{10}$ & $\mathrm{HI}$ & VHI & MI & $\mathrm{HI}$ & $\mathrm{NI}$ \\
\hline
\end{tabular}

For example, the intuitionistic judgments for social dimension given by manager1 is shown in Table VIII.

TABLE VIII

MANAGER ${ }^{1}$ INTUITIONISTIC JUDGMENTS FOR SOCIAL DIMENSION

\begin{tabular}{|l|l|l|l|l|l|}
\hline Manager $^{1}$ & $\mathbf{C}_{\mathbf{1 1}}$ & $\mathbf{C}_{\mathbf{1 2}}$ & $\mathbf{C}_{\mathbf{1 3}}$ & $\mathbf{C}_{\mathbf{1 4}}$ & $\mathbf{C}_{\mathbf{1 5}}$ \\
\hline $\mathrm{C}_{11}$ & $\mathrm{O}$ & $\mathrm{HI}$ & $\mathrm{LI}$ & $\mathrm{LI}$ & $\mathrm{VHI}$ \\
\hline $\mathrm{C}_{12}$ & $\mathrm{MI}$ & $\mathrm{O}$ & $\mathrm{LI}$ & $\mathrm{HI}$ & $\mathrm{MI}$ \\
\hline $\mathrm{C}_{13}$ & $\mathrm{HI}$ & $\mathrm{HI}$ & $\mathrm{O}$ & $\mathrm{HI}$ & $\mathrm{HI}$ \\
\hline $\mathrm{C}_{14}$ & $\mathrm{HI}$ & $\mathrm{VHI}$ & $\mathrm{MI}$ & $\mathrm{O}$ & $\mathrm{MI}$ \\
\hline $\mathrm{C}_{15}$ & $\mathrm{HI}$ & LI & MI & LI & $\mathrm{O}$ \\
\hline
\end{tabular}




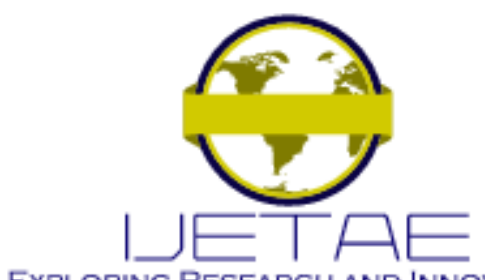

\section{EXPLORING RESEARCH AND INNOVATIONS}

\section{International Journal of Emerging Technology and Advanced Engineering}

Website: www.ijetae.com (E-ISSN 2250-2459, Scopus Indexed, ISO 9001:2008 Certified Journal, Volume 12, Issue 02, February 2022)

- Construct the Direct Relation IF Matrix A:

We applied an IFWA operator, for calculated the aggregated IF Decision Matrix according to the manager1 opinions by using Equation (5), we obtain the Table IX:

TABLE IX

THE AgGREgated IF RELATION MATRIX FOR ECONOMIC DIMENSION

\begin{tabular}{|c|c|c|c|c|c|}
\hline $\mathbf{A}$ & $\mathbf{C}_{\mathbf{1}}$ & $\mathbf{C}_{\mathbf{2}}$ & $\mathbf{C}_{\mathbf{3}}$ & $\mathbf{C}_{\mathbf{4}}$ & $\mathbf{C}_{\mathbf{5}}$ \\
\hline $\mathrm{C}_{1}$ & $(0.00,1.00$ & $(0.68,0.26$ & $(0.85,0.13$ & $(0.59,0.36$ & $(0.81,0.18$ \\
& $, 0.00)$ & $, 0.06)$ & $, 0.02)$ & $, 0.05)$ & $, 0.01)$ \\
\hline $\mathrm{C}_{2}$ & $(0.90,0.10$ & $(0.00,1.00$ & $(0.62,0.32$ & $(0.59,0.36$ & $(0.40,0.51$ \\
& $, 0.00)$ & $, 0.00)$ & $, 0.06)$ & $, 0.05)$ & $, 0.09)$ \\
\hline $\mathrm{C}_{3}$ & $(0.90,0.10$ & $(0.35,0.60$ & $(0.00,1.00$ & $(0.51,0.41$ & $(0.90,0.10$ \\
& $, 0.00)$ & $, 0.05)$ & $, 0.00)$ & $, 0.08)$ & $, 0.00)$ \\
\hline $\mathrm{C}_{4}$ & $(0.82,0,16$ & $(0.75,0.20$ & $(0.75,0.20$ & $(0.00,1.00$ & $(0.51,0.41$ \\
& $, 0,02)$ & $, 0.05)$ & $, 0.05)$ & $, 0.00)$ & $, 0.08)$ \\
\hline $\mathrm{C}_{5}$ & $(0.85,0.13$ & $(0.60,0.35$ & $(0.75,0.20$ & $(0.60,0.35$ & $(0.00,1.00$ \\
& $, 0.02)$ & $, 0.05)$ & $, 0.05)$ & $, 0.05)$ & $, 0.00)$ \\
\hline
\end{tabular}

- Construct the Defuzzify the Direct Relation IF Matrix A:

To construct A, we use the Equation (7). We obtain the Table $\mathrm{X}$ as follow.

TABLE X

THE DEFUZZIFIED AGGREGATED IF RELATION MATRIX FOR ECONOMIC DIMENSION

\begin{tabular}{|l|l|l|l|l|l|}
\hline $\mathbf{X}$ & $\mathbf{C}_{\boldsymbol{1}}$ & $\mathbf{C}_{\mathbf{2}}$ & $\mathbf{C}_{\mathbf{3}}$ & $\mathbf{C}_{\mathbf{4}}$ & $\mathbf{C}_{\mathbf{5}}$ \\
\hline $\mathrm{C}_{1}$ & -1 & 0.42 & 0.72 & 0.23 & 0.63 \\
\hline $\mathrm{C}_{2}$ & 0.8 & -1 & 0.30 & 0.23 & -0.11 \\
\hline $\mathrm{C}_{3}$ & 0.8 & -0.25 & -1 & 0.1 & 0.8 \\
\hline $\mathrm{C}_{4}$ & 0.66 & 0.50 & 0.55 & -1 & 0.1 \\
\hline $\mathrm{C}_{5}$ & 0.72 & 0.25 & 0.55 & 0.25 & -1 \\
\hline
\end{tabular}

- Construct the Normalize the Direct Relation IF Matrix N:

With the Equation (9), we get N, as shown in Table XI.

TABLE XI

THE NORMALIZED MATRIX FOR ECONOMIC DIMENSION

\begin{tabular}{|l|l|l|l|l|l|}
\hline $\mathbf{N}$ & $\mathbf{C}_{\mathbf{1}}$ & $\mathbf{C}_{\mathbf{2}}$ & $\mathbf{C}_{\mathbf{3}}$ & $\mathbf{C}_{\mathbf{4}}$ & $\mathbf{C}_{\mathbf{5}}$ \\
\hline $\mathrm{C}_{1}$ & -0.51 & 0.21 & 0.37 & 0.12 & 0.32 \\
\hline $\mathrm{C}_{2}$ & 0.41 & -0.51 & 0.15 & 0.12 & -0.07 \\
\hline $\mathrm{C}_{3}$ & 0.41 & -0.13 & -0.51 & 0.05 & 0.41 \\
\hline $\mathrm{C}_{4}$ & 0.34 & 0.26 & 0.28 & -0.51 & 0.05 \\
\hline $\mathrm{C}_{5}$ & 0.38 & 0.13 & 0.28 & 0.13 & -0.51 \\
\hline
\end{tabular}

- Construct the Total Relation IF Matrix T:

We use the Equation (10) to construct T, as follow in Table XII.

TABLE XII

THE TOTAL RELATION IF MATRIX T FOR ECONOMIC DIMENSION

\begin{tabular}{|l|l|l|l|l|l|}
\hline $\mathbf{N}$ & $\mathbf{C}_{\mathbf{1}}$ & $\mathbf{C}_{\mathbf{2}}$ & $\mathbf{C}_{\mathbf{3}}$ & $\mathbf{C}_{\mathbf{4}}$ & $\mathbf{C}_{\mathbf{5}}$ \\
\hline $\mathrm{C}_{1}$ & -0.13 & 0.14 & 0.30 & 0.11 & 0.26 \\
\hline $\mathrm{C}_{2}$ & 0.28 & -0.29 & 0.17 & 0.09 & 0.07 \\
\hline $\mathrm{C}_{3}$ & 0.31 & 0.01 & -0.19 & 0.08 & 0.29 \\
\hline $\mathrm{C}_{4}$ & 0.31 & 0.16 & 0.25 & -0.28 & 0.15 \\
\hline $\mathrm{C}_{5}$ & 0.33 & 0.11 & 0.26 & 0.11 & -0.20 \\
\hline
\end{tabular}

- Calculate the cause and effect groups:

To calculate $\mathrm{R}$ and $\mathrm{C}$, we use the Equations (12) and (13) respectively. The result is showed in Table XIII as follow.

TABLE XIII

THE CAUSE AND EFFECT GROUPS

\begin{tabular}{|l|l|l|l|l|l|l|l|}
\hline & $\mathbf{R}$ & $\mathbf{C}$ & $\mathbf{R}+\mathbf{C}$ & Rank & R-C & Rank & Group \\
\hline $\mathrm{C}_{1}$ & 1.10 & 0.68 & 1.78 & 1 & 0.42 & 1 & Cause \\
\hline $\mathrm{C}_{2}$ & 0.13 & 0.32 & 0.45 & 5 & -0.19 & 4 & Effect \\
\hline $\mathrm{C}_{3}$ & 0.79 & 0.50 & 1.29 & 2 & 0.29 & 2 & Cause \\
\hline $\mathrm{C}_{4}$ & 0.11 & 0.60 & 0.71 & 4 & -0.49 & 5 & Effect \\
\hline $\mathrm{C}_{5}$ & 0.58 & 0.61 & 1.19 & 3 & -0.03 & 3 & Effect \\
\hline
\end{tabular}

- Calculate the weights of criteria:

Table XIV shows the result of calculating the weights of the criteria selected with Equation (14) as follows.

TABLE XIV

THE WEIGHTS OF CRITERIA

\begin{tabular}{|l|l|l|l|l|l|}
\hline \multicolumn{2}{|l|}{ Dimension } & \multicolumn{2}{l|}{ Environmental } & \multicolumn{2}{l|}{ Social } \\
\hline Economic & Weight & Criteria & Weight & Criteria & Weight \\
\hline Criteria & 0.32 & $\mathrm{C}_{6}$ & 0.32 & $\mathrm{C}_{11}$ & 0.15 \\
\hline $\mathrm{C}_{1}$ & 0.09 & $\mathrm{C}_{7}$ & 0.09 & $\mathrm{C}_{12}$ & 0.21 \\
\hline $\mathrm{C}_{2}$ & 0.23 & $\mathrm{C}_{8}$ & 0.23 & $\mathrm{C}_{13}$ & 0.23 \\
\hline $\mathrm{C}_{3}$ & 0.15 & $\mathrm{C}_{9}$ & 0.15 & $\mathrm{C}_{14}$ & 0.22 \\
\hline $\mathrm{C}_{4}$ & 0.21 & $\mathrm{C}_{10}$ & 0.21 & $\mathrm{C}_{15}$ & 0.19 \\
\hline $\mathrm{C}_{5}$ & \multicolumn{4}{|l}{} \\
\hline
\end{tabular}

Step 5: Calculates values of selected criteria

We follow the equation developed in our article [17], we get the Table XV: 


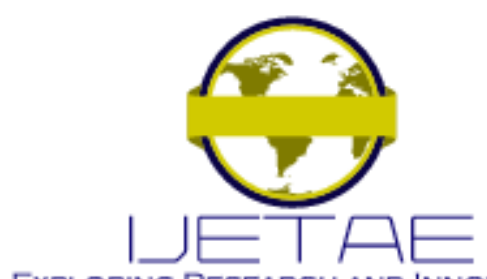

EXPLORING RESEARCH AND INNOVATIONS

International Journal of Emerging Technology and Advanced Engineering

Website: www.ijetae.com (E-ISSN 2250-2459, Scopus Indexed, ISO 9001:2008 Certified Journal, Volume 12, Issue 02, February 2022)

TABLE XV

THE VALUES OF THE CRITERIA

\begin{tabular}{|c|c|c|c|c|c|}
\hline \multicolumn{6}{|c|}{ Dimension } \\
\hline \multicolumn{2}{|c|}{ Economic } & \multicolumn{2}{|c|}{ Economic } & \multicolumn{2}{|c|}{ Economic } \\
\hline Criteria & Value & Criteria & Value & Criteria & Value \\
\hline $\mathrm{C}_{1}$ & 0.32 & $\mathrm{C}_{6}$ & 0.32 & $\mathrm{C}_{11}$ & 0.15 \\
\hline $\mathrm{C}_{2}$ & 0.09 & $\mathrm{C}_{7}$ & 0.09 & $\mathrm{C}_{12}$ & 0.21 \\
\hline $\mathrm{C}_{3}$ & 0.23 & $\mathrm{C}_{8}$ & 0.23 & $\mathrm{C}_{13}$ & 0.23 \\
\hline $\mathrm{C}_{4}$ & 0.15 & $\mathrm{C}_{9}$ & 0.15 & $\mathrm{C}_{14}$ & 0.22 \\
\hline $\mathrm{C}_{5}$ & 0.21 & $\mathrm{C}_{10}$ & 0.21 & $\mathrm{C}_{15}$ & 0.19 \\
\hline
\end{tabular}

Step 6: Calculate the weight of SD dimensions:

We select a scenario where the dimension weights are equal as follow:

$$
W_{\text {economic }}=W_{\text {environmental }}=W_{\text {social }}=1 / 3
$$

Step 7: Calculate the index of dimension of SD:

Using the values of the criteria calculated by the equation cited in our work [17], and the Equations (15), (16) and (17), we can calculate the index of the three dimensions of SD of supplier ${ }^{1}$. The Table XVI showed the values of the criteria calculated for the supplier ${ }^{1}$.

TABLE XVI

THE VALUES OF THE CRITERIA CALCULATED FOR THE SUPPLIER ${ }^{1}$

\begin{tabular}{|l|l|l|l|l|l|}
\hline \multicolumn{5}{|l|}{ Dimension } & \multicolumn{2}{l|}{ Economic } & \multicolumn{2}{l|}{ Economic } \\
\hline Economic & $\begin{array}{l}\text { Criterio } \\
\text { n value }\end{array}$ & Criteria & $\begin{array}{l}\text { Criterion } \\
\text { value }\end{array}$ & $\begin{array}{l}\text { Criteria } \\
\text { Criterion } \\
\text { value }\end{array}$ \\
\hline $\mathrm{C}_{1}$ & 0.66 & $\mathrm{C}_{6}$ & 0.77 & $\mathrm{C}_{11}$ & 0.87 \\
\hline $\mathrm{C}_{2}$ & 0.75 & $\mathrm{C}_{7}$ & 0.71 & $\mathrm{C}_{12}$ & 0.45 \\
\hline $\mathrm{C}_{3}$ & 0.56 & $\mathrm{C}_{8}$ & 0.69 & $\mathrm{C}_{13}$ & 0.76 \\
\hline $\mathrm{C}_{4}$ & 0.78 & $\mathrm{C}_{9}$ & 0.56 & $\mathrm{C}_{14}$ & 0.56 \\
\hline $\mathrm{C}_{5}$ & 0.67 & $\mathrm{C}_{10}$ & 0.45 & $\mathrm{C}_{15}$ & 0.76 \\
\hline
\end{tabular}

The index calculated of supplier1 are: $I_{\text {economique }}=0.67, \quad I_{\text {environmental }}=0.65$ and $I_{\text {social }}=0.67$.

Step 8: Calculate Index of interfaces of SD:

By using the Equations (18), (19) and (20) we can calculate the index of the viable, livable and equitable interface of SD for the supplier1, as follow respectively: $I_{\text {viable }}=4.31, I_{\text {linable }}=4.44$ and $I_{\text {equitable }}=4.32$.
Step 9: Calculate the supplier sustainability performance index:

To calculate the supplier sustainability performance index for the supplier1, we use the Equation (21).

The calculi gave as result: $I_{\text {Sustinaibility }}=82.63 \%$.

\section{RESULTS AND Discussion}

From the Table 13, we obtain the importance between criteria of the economic dimension as follow: According to the axe $(\mathrm{R}+\mathrm{C}): \mathrm{C}_{1}>\mathrm{C}_{3}>\mathrm{C}_{5}>\mathrm{C}_{4}>\mathrm{C}_{2}$ and According to the axe (R-C): $\mathrm{C}_{1}>\mathrm{C}_{3}>\mathrm{C}_{5}>\mathrm{C}_{2}>\mathrm{C}_{4}$.

The Figures II, III and IV showed respectively the diagram of cause-effect relationships between economic, environmental and social criteria, as follow:

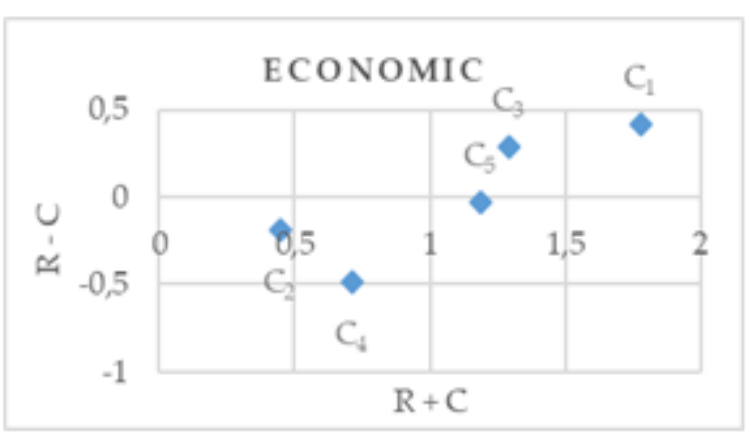

FIGURE II THE CAUSAL DIAGRAM OF ECONOMIC DIMENSION

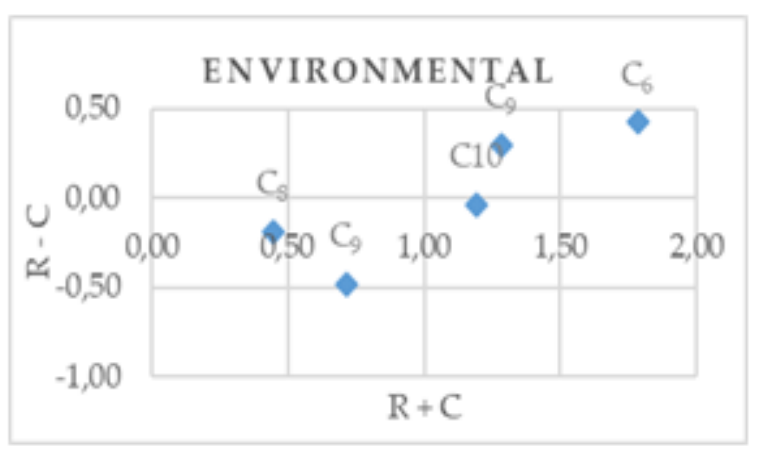

FIGURE III THE CAUSAL DIAGRAM OF ENVIRONMENT DIMENSION 


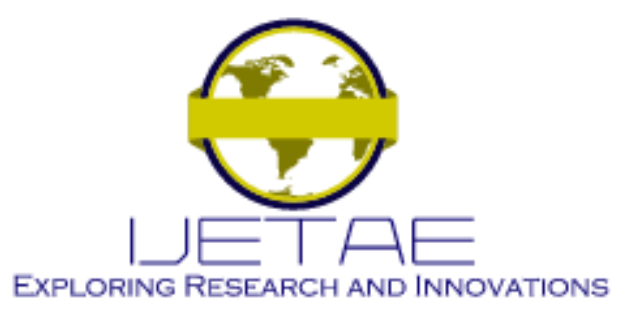

International Journal of Emerging Technology and Advanced Engineering Website: www.ijetae.com (E-ISSN 2250-2459, Scopus Indexed, ISO 9001:2008 Certified Journal, Volume 12, Issue 02, February 2022)

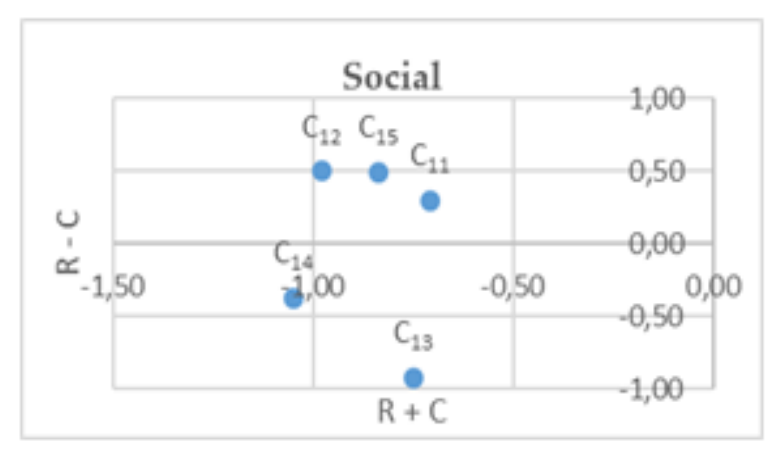

FIGURE IV THE CAUSAL DIAGRAM OF SOCIAL DIMENSION

We apply the same steps to calculate the sustainability performance index of the supplier1 on the other suppliers, the Table XVII shows these calculi as follow:

TABLE XVII

THE SUSTAINABILITY PERFORMANCE INDEX

\begin{tabular}{|c|c|c|}
\hline Supplier & $\begin{array}{l}\text { Sustainability } \\
\text { performance index }\end{array}$ & Rank \\
\hline Supplier $^{1}$ & $82.63 \%$ & 2 \\
\hline Supplier ${ }^{2}$ & $70.23 \%$ & 4 \\
\hline Supplier $^{3}$ & $75.03 \%$ & 3 \\
\hline Supplier ${ }^{4}$ & $30.98 \%$ & 5 \\
\hline Supplier & $87.10 \%$ & 1 \\
\hline
\end{tabular}

From the Table XVII, the best supplier who respects the concept of the sustainable of development is the supplier number 5 .

The results obtained show that our developed model makes it possible to classify and select the best suppliers.

\section{CONCLUSIONS}

This paper develops a decision making model based on IFS DEMATEL model to choice the best supplier in terms of respect for SD. We use IFS to result the problem of hesitation in uncertain problem, and the DEMATEL to obtain the weight of SD criteria selected.

Our contribution and innovation of this article are as follows:

- It takes into consideration the link between the economic and environmental dimension. This is what we call to be viable.
- It takes into consideration the link between the economic and social dimension. This is what we call equality.

- It takes into consideration the link between the environmental and economic dimension. This is what we call to be livable.

- It presents a simple model that can be adopted to calculate and assess the sustainability performance of suppliers to companies operating in any sector.

In our next work, we will take more criteria in the process of calculating the weight of decision-makers depending on the number of years of experience.

\section{REFERENCES}

[1] A. Parmigiani, R. D. Klassen, M. V. Russo. Efficiency meets accountability: Performance implications of supply chain configuration, control, and capabilities. Journal of Operations Management 29 (2011) 212-223; doi:10.1016/j.jom.2011.01.001.

[2] Patchara Phochanikorn and Chunqiao Tan. A New Extension to a Multi-Criteria Decision-Making Model for Sustainable Supplier Selection under an Intuitionistic Fuzzy Environment. Sustainability 2019, 11, 5413; doi:10.3390/su11195413.

[3] Reza Alikhani, S.A. Torabi, Nezih Altay, Strategic supplier selection under sustainability and risk criteria, International Journal of Production Economics (2018), doi:10.1016/j.ijpe.2018.11.018.

[4] Tirkolaee EB, Mardani A, Dashtian Z, Soltani M, Weber G-W, A novel hybrid method using fuzzy decision making and multiobjective programming for sustainable-reliable supplier selection in two-echelon supply chain design, Journal of Cleaner Production (2019), doi: https://doi.org/10.1016/j.jclepro.2019.119517.

[5] Zadeh, L. Fuzzy sets. Inf. Control 1965, 8, 338-353.

[6] Atanassov, K. Intuitionistic fuzzy sets. In Proceedings of the VII ITKR's Session, Sofia, Bulgaria, 7-9 June 1983 (Deposed in Central Sci.- Techn. Library of Bulg. Acad. of Sci., 1697/84) (in Bulgaria); reprinted in Int. J. Bioautom. 2016, 20, S1-S6.

[7] K. T. Atanassov. Intuitionistic fuzzy sets. Fuzzy sets and systems, 20:87-96, 1986.

[8] H.S. Kilic, A.E. Demirci and D. Delen, An integrated decision analysis methodology based on IF-DEMATEL and IF-ELECTRE for personnel selection, Decision Support Systems (2019), https://doi.org/10.1016/j.dss.2020.113360.

[9] Büyüközkan, G., Göçer, F. and Karabulut, Y. A new group decision making approach with IF AHP and IF VIKOR for selecting hazardous waste carriers," Measurement. 2019 Vol. 134, pp. 66-82.

[10] Fontela, E., Gabus, A. DEMATEL, innovative methods. Rep. No. 2, "Structural analysis of the world problematique (methods)", Battelle Geneva Research Institute (1974).

[11] Lanndon, O., Kafferine, Y. $\quad$ SEPS. 2020. https://doi.org/10.1016/j.seps.2020.100911. 


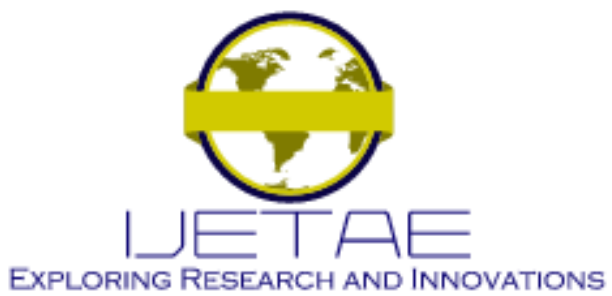

International Journal of Emerging Technology and Advanced Engineering Website: www.ijetae.com (E-ISSN 2250-2459, Scopus Indexed, ISO 9001:2008 Certified Journal, Volume 12, Issue 02, February 2022)

[12] Büyüközkan, Güç., Güleryüz, S., Karpak, B. A new combined IFDEMATEL and IF-ANP approach for CRM partner evaluation, IJPE 2017, doi: 10.1016/j.ijpe.2017.05.012.

[13] Govindan, K., et al. Intuitionistic fuzzy based DEMATEL method for developing green practices and performances in a green supply chain. Expert Systems with Applications (2015), http://dx.doi.org/10.1016/j.eswa.2015.04.030.

[14] Lazim, A., Norsyahida, Z., Huchang L., Enrique H., Abdullah A. An interval-valued intuitionistic fuzzy DEMATEL method combined with Choquet integral for sustainable solid waste management. j.engappai, 2019 https://doi.org/10.1016/j.engappai.2019.04.005.

[15] M. Amiri , M. Hashemi-Tabatabaei , M. Ghahremanloo , M. Keshavarz-Ghorabaee , E. K. Zavadskas \& A. Banaitis (2020): A new fuzzy BWM approach for evaluating and selecting a sustainable supplier in supply chain management, International Journal of Sustainable Development \& World Ecology, DOI: 10.1080/13504509.2020.1793424.

[16] Jing Li, Hong Fang, Wenyan Song. Sustainable supplier selection based on SSCM practices: A rough cloud TOPSIS approach. Journal of Cleaner Production (2019). https://doi.org/10.1016/j.jclepro.2019.03.070.

[17] Giannakis M, Dubey R, Vlachos I, Ju Y, Supplier sustainability performance evaluation using the analytic network process, Journal of Cleaner Production (2019), doi: https://doi.org/10.1016/j.jclepro.2019.119439.
[18] M. Abdel-Baset, Victor Chang, Abduallah Gamal, Florentin Smarandache. An integrated neutrosophic ANP and VIKOR method for achieving sustainable supplier selection: A case study in importing field. Computers in Industry (2019). https://doi.org/10.1016/j.compind.2018.12.017.

[19] Z. Chen, X. Ming, T. Zhou et al., Sustainable supplier selection for smart supply chain considering internal and external uncertainty: An integrated rough-fuzzy approach, Applied Soft Computing Journal (2019), doi: https://doi.org/10.1016/j.asoc.2019.106004.

[20] Longyu S., Linwei H., Fengmei Y., Lijie G. The Evolution of Sustainable Development Theory: Types, Goals, and Research Prospects. Sustainability 2019, 11, 7158; doi:10.3390/su11247158.

[21] El Mariouli, O.; Abouabdellah, A. A new model of supplier's selection for sustainable supply chain management. Advances in Science, ASTES 2019, Vol. 4, No. 2, 251-269.

[22] El Mariouli, O., Abouabdellah, A.: Model for assessing the economic, environmental and social performance of the supplier. In: 4th IEEE International Conference on Logistics Operations Management (GOL'2018), Lehavre, France (2018).

[23] $\mathrm{Xu}, \mathrm{Z}$. Intuitionistic preference relations and their application in group decision making. Inf. Sci. 2007, 177, 2363-2379. 